\title{
Liturgical Function and Gregorian Chant in the Music of Paulus Bucenus
}

\author{
Agnieszka Leszczyńska / a.z.leszczynska@uw.edu.pl \\ Instytut Muzykologii, Uniwersytet Warszawski, Warszawa, PL
}

\begin{abstract}
Paulus Bucenus after studies in Greifswald and few years spent in Toruń moved to Riga where he was the school cantor till the end of his life in 1586. He composed almost exclusively sacred music. His Passio Domini nostri Jesu Christi was published in Szczecin in 1578 and 155 other compositions are preserved in the uncomplete manuscript prepared by him in Riga (D-B 40074). Among his works there are masses, motets, hymns, responsories, magnificats. Chant melodies are clearly recognizable in a number of compositions. In hymns they are often used in long values in discantus. In the Passio and some motets quasi-reciting tone is evident. Sometimes chant melodies used in very long values contrast with other voices ornamentally structured.
\end{abstract}

\section{Key words}

Paulus Bucenus, motet, mass, magnificat, Passion, Gregorian chant, cantus firmus 
All the known facts about Paulus Bucenus's life point to the conclusion that he had strong links to the Baltic region. In 1568, by then as a renowned musician, he immatriculated at the university in Greifswald. ${ }^{1}$ From about 1570 until at least December 1571 he was employed as a cantor in Torun/Thorn, presumably at the church of St John the Baptist and St John the Evangelist. In 1578 his Passio Domini Nostri Jesu Christi was published by the printing house of Andreas Kellner in Szczecin/Stettin. ${ }^{2}$ By then he was already a cantor at the cathedral school in Riga, where he remained until his death in 1586. It was there that Bucenus, towards the end of his life, produced the monumental manuscript titled Opus musicae ecclesiae rigensis. He included 155 of his compositions in it, largely liturgical, which were probably written during various periods in his career. ${ }^{3}$

We cannot be certain as to where Bucenus was born. On the basis of the entry in the immatriculation book of Greifswald university, where he is described as Paulus Bucenus Philorhodus Holsata, the hypothesis has been put forward that he was born in Holstein. ${ }^{4}$ Since this is the only document where the appellation "Holsata" makes an appearance, it seems that the description "Philorhodus", used by the composer himself on many occasions, provides more reliable grounds for drawing conclusions about the composer's birthplace. This trail had already been taken up as early as 1931, with the idea that the Grecianised form "Philorhodus" may come from the name Lieberose/Luboraz, a city in Lower Lusatia located some $30 \mathrm{~km}$ north of Cottbus/Chóśebuz. Consequently, the name Bucenus (or Bucaenus) may originate from the name of a village Butzen/Bucyn located near Lieberose. ${ }^{5}$ Indirect evidence of possible links between the composer and this region may be provided by the fact that, during the 1580s, at Krosno Odrzańskie/ Crossen, which is situated relatively nearby, there lived an author of occasional poems who was called Christoph Bucenus; ${ }^{6}$ in view of the name not being very common, he may have been related to the composer. ${ }^{7}$ In the context of the hypothetical Lusatian origins of Paulus Bucenus we may conclude that he was erroneously described as "Holsata" instead of "Lusata" in the immatriculation book of the university in Greifswald. It is also worth drawing attention to the fact that, apart from the Riga manuscript, most of the early manuscripts containing works by Paulus Bucenus were written not far from Lusa-

1 "Paulus Bucenus, philorhodus, Holsata, musicus, qui in artis musices honorem gratis est inscriptus". See FRIEDLÄNDER, Ernst et al. (eds.). Aeltere Universitäts-Matrikeln II. Universität Greifswald, vol. 1: 1456-1645, Leipzig: S. Hirtzel, 1893, p. 292.

2 RISM: B 4860. Modern edition: MADGWICK, Paul (ed.). Passio Domini nostri Jesu Christi, Musicis numeris exornata, in usum Ecclesiae Rigensis à Paulo Buceno Philorodo, Scholae Rigensis Cantore. 1578. Riga: Musica Baltica Ltd, 1995.

3 Staatsbibliothek zu Berlin - Preußischer Kulturbesitz, Ms Mus. 40074 [D-B 40074].

4 BLANKENBURG, Walter. Bucenus, Paulus. In The New Grove Dictionary of Music and Musicians. Stanley Sadie - John Tyrrell (eds.), 2nd Edition, vol. 4, London: Macmillan Publishers Ltd, 2001, pp. 531-532.

5 KEUSSLER, Gerhard von. Paulus Bucaenus, Riga: G. Löffler, 1931, p. 10.

6 He is one of the authors of the Gratulationes in honorem... Eliae Andreae Saxohalensis, cum illi Magisterii Philosophici gradus in Academia Francofordiana.. ab amici scripti. Frankfurt/Oder: Andreas Eichorn, 1588.

7 Documents from Lieberose indicate that persons called Butzena did live in that city shortly after Bucenus's time, see MADGWICK, op. cit., p. II. 
tia, in Silesia - at Wrocław/Breslau or Oleśnica/Oels, which may point to the composer having some contacts with that region as well.

It is not known whether Lieberose, Bucenus's supposed place of birth, was dominated by Catholics or by Protestants during his youth. ${ }^{8}$ It is not until 1574 that the local Kirchenordnung provides a clear indication that the city had a Lutheran character. According to its instructions, local liturgy continued to use Latin on feast days and on Fridays, but services held on other days gave voice to the German language, and under some circumstances also to Lusatian. ${ }^{9}$ Assuming that the Kirchenordnung from 1574 confirmed a tradition that had already been established for a number of years, and that Bucenus spent his youth in that area, we might suppose that he had the opportunity of encountering liturgical texts, both Latin and German, i.e., such as he later used in his music, when he was still a young man. Presumably he spent most of his creative life in a Lutheran community, but undoubtedly he also dealt with the Catholic liturgy - at least in Torun, where the church of St John the Baptist and St John the Evangelist was used alternately by the Lutherans and the Catholics. Bucenus himself was certainly a self-declared Lutheran, as evidenced by, among other things, the precept "Soli Deo gloria," emblematic of this faith, which appears after each composition in the collection he assembled in Riga. The music of Bucenus provides us with many examples of the vitality of the Gregorian chant tradition within the Evangelical-Augsburg environment.

The manuscript titled Opus musicae ecclesiae rigensis was written during the years 15831584. It consists of two two-part volumes and contains all of the known works left by the composer with the exception of his Passion ${ }^{10}$. What has survived until the present day, in incomplete condition, are two partbooks (Cantus, Bassus) from the first volume and three partbooks (Cantus, Tenor, Bassus) from the second one. Bucenus prepared his work with great care, presumably as the basis for a future edition. He not only gave a title to the whole collection, but also introduced title pages for each of the four parts, and lists of contents at the end of each part. At the beginning of the collection there is also an extensive dedication in Latin to the councillors of the city of Riga. The manuscript was divided as follows:

Tomus primus

- Sacrae aliquot cantiones sex vocum ad tria contrapuncti genera accomodatae musicis instrumentis

8 KRÜGER, Karl. Mitteilungen aus der Geschichte der Stadt Lieberose und der Gegend zunächst bis 1700. Frankfurt/Oder: Selbstverlag des Verfassers, 1891, p. 54.

9 Ibidem, p. 63.

10 For more on the subject of this source, in greater or lesser detail, see: KEUSSLER, op. cit., pp. 11-14, HEMMING, Sture. Cantor Paulus Bucenus and his Opus Musicum Ecclesiae Rigensis. Journal of Baltic Studies. 1977, vol. 8, pp. 232-237, MADGWICK, Paul. Music in Riga towards the end of the 16th century and Paulus Bucenus Philorhodus. In Music History Writing and National Culture: Proceedings of a Seminar. Urve Lippus (ed.). Tallinn: Eeste keele instituut, 1995, pp. 44-53 [= online, cit. 2015-11-28]. URL: https://www.jiscmail. ac.uk/cgi-bin/filearea.cgi?LMGT1=MED-AND-REN-MUSIC\&a=get\&f=/riga.txt; LESZCZYŃSKA, Agnieszka. Confessionalism in the Music of Paul Bucenus. In Musica Antiqua Europeae Orientalis, Acta Musicologica, vol. XIV. Irena Poniatowska (ed.), Bydgoszcz: Filharmonia Pomorska im. I. Paderewskiego, 2008, pp. 81-87. 
scholisquae aptissimae decantatae [55 compositions]

- Sacrae aliquot cantiones quinque et quatuor vocum ad tria contrapuncti genera accomodatae musicis instrumentis scholisquae aptissimae decantatae [45 compositions]

\section{Tomus secundus}

- Missae aliquot quatuor, Quinque, sex et octo vocum ad clarissimorum musicorum motetas et sacros quosdam tenores accomodatae [24 compositions]

- Preces vespertine (responsoria, hymni, Magnificat et aliae quaedam cantiones quae in p[rae]cipuis diebus festis et totum annum in Ecclesia Rigensi decantantur quinque et sex vocibus concinnatae) [31 compositions].

This division of Opus musicum suggests that the liturgical compositions are principally gathered in the second volume, intended to be used during masses and vespers at the Riga church, while the first volume contains religious works without a specific function, which can also be performed by pupils. The didactic aim of this volume is indirectly emphasised by the comment about the three kinds of counterpoint employed. However, this volume also contains settings of liturgical texts, sometimes based on chant cantus firmus.

Let us examine first the contents of the second volume. The majority of Bucenus's 24 mass compositions belong to the missa parodia genre and are based on motets by various composers. The less numerous masses based on cantus firmus technique make use of Protestant hymns and, to a slight degree, Gregorian chant as cantus prius factus. None of Bucenus's masses contains a Credo, which fits in with the practice of the Lutheran church. In tenor of the mass Iam non dicam $(2 / 1 / 2)^{11}$ based on the motet by Dominique Phinot, the composer included between Gloria and Sanctus the annotation: "loco Patrem motet et Germanica Cantio Wir glauben". A comment of this kind may indicate that he was used to Catholic five-part masses, and that the original version of this particular composition may have contained a Credo. ${ }^{12}$

The only mass by Bucenus based, at least partly, on Gregorian chant is Missa De beata Trinitate (2/1/11), where the antiphon Gloria tibi Trinitas, intended for the feast of the Holy Trinity, is used as the long-note cantus firmus. It is located in the tenor, together with the text, and its notation reflects the ligatures of chant notation. The antiphon, divided into three parts, appears in Kyrie and Gloria. Sanctus and Agnus Dei do not have chant quotations, but it is possible that there were some in the voices which are not preserved.

A different kind of reference to Catholic liturgy is to be found in Bucenus's Kyrie Fons bonitatis. This kind of Kyrie was in general use in Lutheran liturgy, often with the German version of the trope Gott Vater in Ewigkeit. ${ }^{13}$ In his Summum Officium (2/1/20)

11 The consecutive digits refer to the number of volume, part and composition.

12 Kyrie and Gloria of Iam non dicam mass was also written at the beginning of the lost Ms. 100 from the City Library in Wrocław. See BOHN, Emil. Die Musikalischen Handschriften des XVI und XVII Jahrhunderts in der Stadtbibliothek zu Breslau. Breslau, 1890, p. 112.

13 The trope Gott Vater in Ewigkeit was probably used for the first time in the Naumburg hymnbook by Nikolaus 
Bucenus made use of the original Latin version of the trope and placed its full text in all the voices. ${ }^{14} \mathrm{He}$ also introduced a quotation from the melody of the chant Kyrie in the bass, but limited it to the first nine notes.

In the second part of the second volume - entitled Preces Vespertine - there are hymns, responsories and one magnificat (2/2/19, for Visitation) arranged in accordance with the order of the church year. After compositions intended for specific feasts, Bucenus included six magnificats based on different tones. They were composed in the alternatim technique - usually the uneven verses were intended to be performed using the melody of a Gregorian chant. The hymns were written also with the alternatim technique in mind, e.g. Beatus autor saeculi $(2 / 2 / 4)$, which is the second stanza of the hymn for Christmas - A solis ortus cardine. The text of the eighth stanza added under the notes suggests a polyphonic performance of the uneven strophes. Most of the hymn texts used by Bucenus are common for the Catholic and Lutheran churches. The only one absent from the Catholic liturgy is Dicimus grates tibi summe verum (2/2/22) with the Philip Melanchton's text intended for the feast of Archangel Michael.

The presence of chant melodies in compositions included in the second part of the first volume is quite schematic. In the responsories Gregorian chant appears most often in the form of an incipit a few notes in length; for example, in Illuminare, illuminare Jerusalem $(2 / 2 / 5)$ for the feast of Epiphany, the chant melody is limited to a six-note quotation at the beginning of the discantus. The situation is different in the hymns - in the majority of these the whole Gregorian melody in long rhythmic values is located in the highest voice, for example in Qui paracletus diceris $(2 / 2 / 16)$ for the feast of the Pentecost. ${ }^{15}$ Sometimes the quoted melody is set in smaller rhythmic values and deviates from the chant model in details, for example in Festum nunc celebre (2/21/4) for Ascension Day. The Easter hymn Salve festa dies (2/2/12) is given an exceptional setting, with the composer quoting only a six-note motif from the Gregorian hymn at the beginning of the discantus, and then giving all the surviving voices free melodic setting. A peculiarity of this work is its triple rhythm with a quasi-dance character, notated in black notes, and repetitions of text units. Thanks to this treatment increases the joyful mood of the Easter hymn (Ex. 1).

Among the seven magnificats composed by Bucenus, four contain longer fragments based on the magnificat tone. They are most numerous in Magnificat quinti toni (2/2/27), where chant recitation appears in the Et exultavit, Sicut locutus and Sicut erat segments in the discantus, and in Quia fecit in the tenor.

The second volume of Opus musicum contains mainly works recommended by Lutheran theologians such as Johann Spangenberg, Lucas Lossius and Johannes Keuchenthal,

\footnotetext{
Medler in 1537. See HAHN Gerhard - HENKYS, Jürgen (eds.). Liederkunde zum Evangelischen Gesangbuch. Heft 6/7, Göttingen: Vandenhoeck \& Ruprecht, 2003, p. 17.

14 He modified the text in the bass and discantus, replacing the fragment „pater ingenite" with the words "amator inclyte“.

15 Second stanza of Veni creator Spiritus.
} 

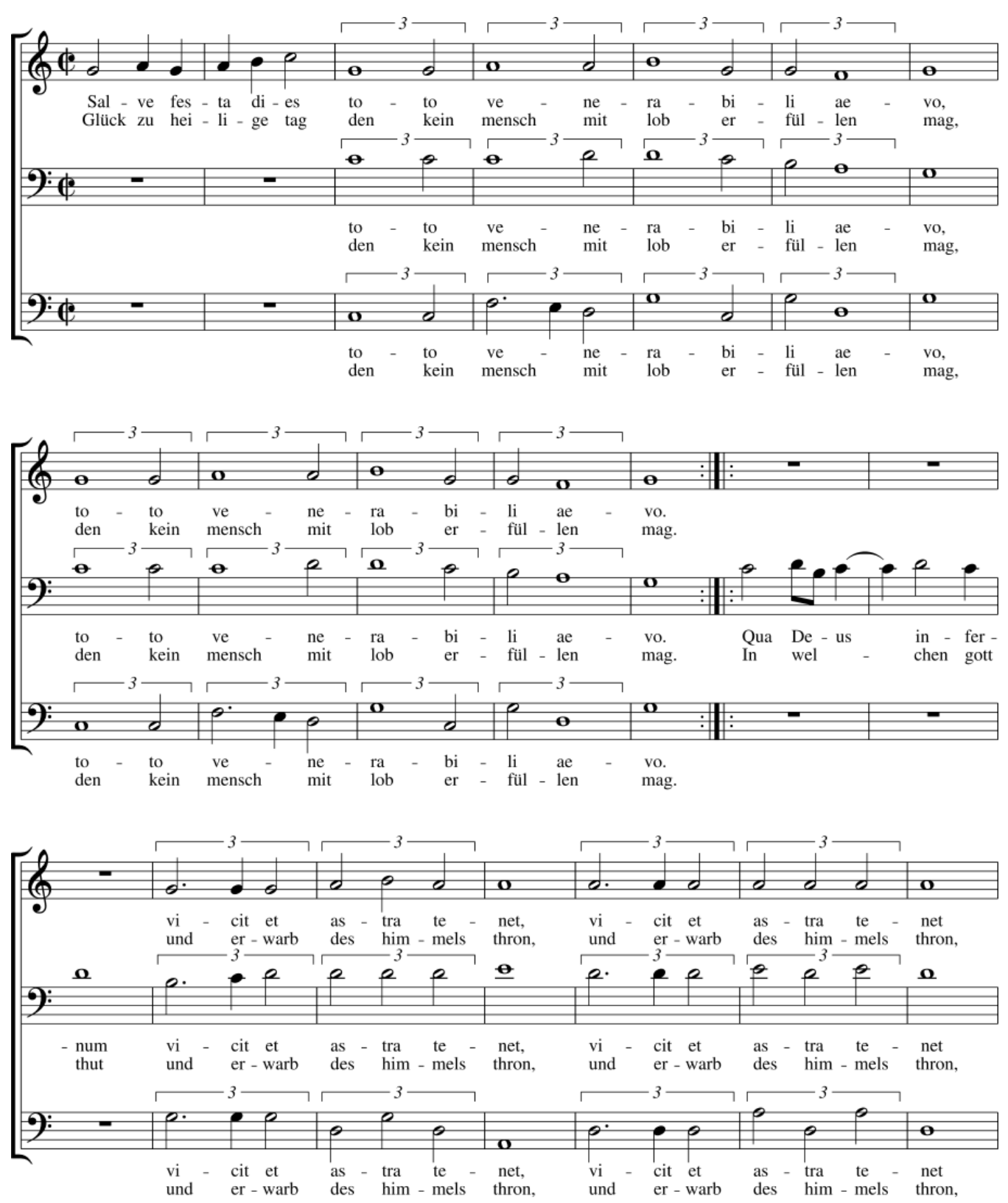

Ex. 1. Paulus Bucenus, Salve festa dies a 6: D, T, B. ${ }^{16}$

$16 \mathrm{D}=$ discantus, $\mathrm{T}=$ tenor, $\mathrm{B}=$ bassus. All transcriptions in this article are made by its author and examples are prepared by Piotr Maculewicz. 
who produced catalogues of Latin chants which could be used in the Augsburg Confession ${ }^{17}$. They are dominated by hymns, which became firmly established in the German tradition as early as the fifteenth century, and were not displaced as a result of the Reformation. It seems, however, that certain ideas used by Bucenus, such as introducing a quasi-dance rhythm into Salve festa dies, were not necessarily in accordance with the Lutheran custom.

The composer's creative approach to the tradition - this time the chant tradition - is even more apparent in the works from the first volume of Opus musicum, those without a specific liturgical function. Bucenus used chant cantus firmus there in a variety of ways. Sometimes he made it the conventional basis for a polyphonic composition, which meant that it could function both as an independent work and as part of liturgy. The motet Salva nos vigilantes $(1 / 2 / 18)$ can serve as an example, with its text taken from the antiphon which in liturgy precedes the canticle Nunc dimittis. In the tenor of this work Bucenus used extensively a Gregorian melody in long rhythmic values, and he began the discantus with a chant incipit. He did not put this motet next to his own setting of Simeon's canticle $(1 / 2 / 12)$, seeming to emphasise in this way the autonomic character of Salva nos, but the structure of this work does not preclude it being used in liturgy.

In the motet Veni Sancte Spiritus reple tuorum corda $(1 / 1 / 11)$ the whole melody of the chant antiphon is quoted in the tenor in long rhythmic values, and its incipit appears in the discantus. This motet with the others which follow it - Nun bitten wir den heiligen Geist and Halleluia Spiritus sancti gratiae - form a group of compositions intended for the Pentecost and each of them is capable of functioning as part of liturgy.

In some of Bucenus's motets we can see links to the Roman tradition which are somewhat closer than would result simply from similarities between the Catholic and Lutheran liturgies. One can quote here as an example the motet Pater noster / Vater unser $(1 / 2 / 19)$. In its tenor the composer used the German translation of this prayer, in fact wilfully changing the expression "wie im Himmel, also auf der Erden" to "auff Erden, wie im

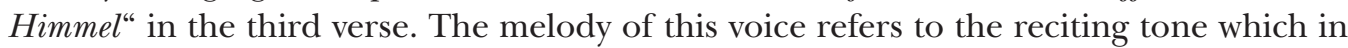
the Catholic church served to perform Pater noster as a chant. Its incipit appears also at the beginning of the discantus, in which is given a Latin text (Ex. 2).

Two motets composed by Bucenus to Marian texts are also a kind of nod towards the Catholic tradition; these are Inviolata es (1/1/16) and Beata es virgo Maria quae Dominum $(1 / 1 / 17)$. The first of these texts may have been used in Catholic liturgy as a sequence or antiphon for various Marian feasts, including Purification and Assumption. The text used by Bucenus has only a few elements shared with the text known from Catholic liturgical books, but at the same time has more similarities with words used by Josquin in his motet Inviolata, integra et casta es Maria (Tab. 1).

17 J. Spangenberg. Cantiones Ecclesiasticae / Kirchengesenge Deutsch. Magdeburg, 1545; L. Lossius. Psalmodia, hoc est cantica sacra veteris ecclesiae selecta. Nuremberg, 1553; J. Keuchenthal. Kirchen Gesenge Latinisch und Deutsch. Wittenberg, 1573. See ZAGER, Daniel. The Cantica sacra (Hamburg, 1588) of Franz Eler: Latin Chant and German Chorales for the Lutheram Liturgy. In Thine the Amen: Essays on Lutheran Church Music in Honor of Carl Schalk. Carlos R. Messerli (ed.), Minneapolis: Lutheran University, 2005, pp. 44-45. 

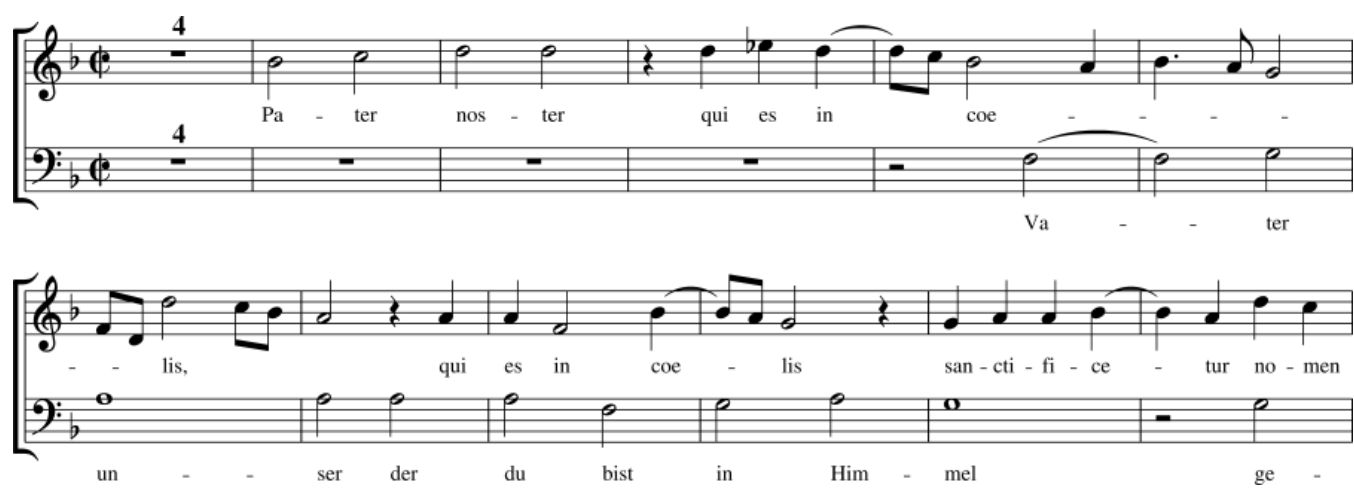

Ex. 2. Paulus Bucenus, Pater noster / Vater unser a 5: D, B.

\begin{tabular}{|l|l|l|}
\hline Bucenus, Inviolata & Gregorian chant & Josquin, Inviolata, 1 pars \\
\hline Inviolata es integra et casta es & Inviolata integra et casta es & Inviolata, integra et casta es \\
virgo mater quae es effecta, de- & $\begin{array}{l}\text { Maria quae es effecta fulgida re- } \\
\text { gis porta o virgo sola Christi ca- }\end{array}$ & $\begin{array}{l}\text { Maria quae es effecta fulgida ca- } \\
\text { elis porta. }\end{array}$ \\
$\begin{array}{l}\text { Christi mater, o Christe fili Dei, et } \\
\text { virginis suscipe pia praeconia }\end{array}$ & $\begin{array}{l}\text { rissima suscipe pia nostra preca- } \\
\text { mina [...] }\end{array}$ & $\begin{array}{l}\text { Suscipe pia. Laudum praecona. } \\
\end{array}$ \\
\hline
\end{tabular}

Tab. 1. Textual comparisons Inviolata es.

Adapting a Marian text to Lutheran needs, which consisted in moving the point of gravity from the Mother of God to Christ, was not necessarily Bucenus's own idea; he might have taken these words from a Protestant collection ${ }^{18}$. The melody of the tenor is in the main an accurate quotation from a chant antiphon and largely corresponds - at times even in terms of rhythm - to the analogous cantus firmus from Josquin's motet (prima pars). The text of the motet Beata es virgo Maria could be taken from the offertory or the responsory for a Marian feast. It has not been possible to find any references to chant in the surviving two voices, but they might have been present in the voices which are now lost.

In some of Bucenus's motets melody has a reciting character. The first part of Deus in adiutorium meum $(1 / 1 / 22)$ is a prayer which begins the liturgy of the hours, above all the vespers. This text is also used in officium defunctorum. Its words come from the Psalm 69 and the chant version of the prayer is recited in the psalm-tone. In the melody of the discantus of the motet Deus in adiutorium the inspiration of the reciting tone is clearly apparent - it is dominated by segments consisting of notes repeated at the same pitch $-c^{2}$ or $\mathrm{d}^{2}$. However, the absence of one repercussa means that it would be difficult to see here the presence of a particular psalm-tone.

18 This text does not appear in Spangenberg's Cantiones. 
In the motet Peccavimus Domine $(1 / 2 / 17)$ the text located in the discantus is a nonliturgical compilation of a verse from the Book of Judith $(7,19)$ and modified Psalm 50 $(50,6)$, constituting a kind of symbolic confession of sins:

Peccavimus Domine cum patribus nostris iniquitatum fecimus ut malum coram te egimus.

The tenor uses an ostinato in the shape of repeating, fifteen times, the initial verse of Psalm 50: Miserere mei Deus. A simple reciting motif referring to the psalm-tone is used here, beginning each time with a different note, first going higher and then lower (from $\mathrm{f}$ to $\mathrm{f}^{1}$ and back to $\mathrm{f}$ ). This technique brings to mind associations with Josquin's motet Miserere mei Deus and it seems that here Bucenus could intentionally make a reference to the work of the older master (Ex. 3).

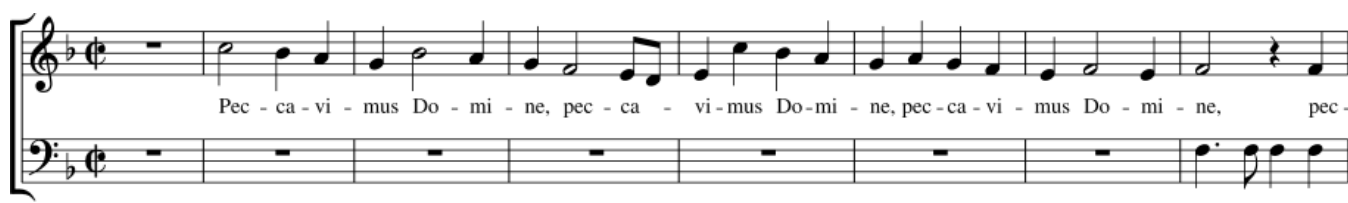

$\mathrm{Mi}$ - se-re - re

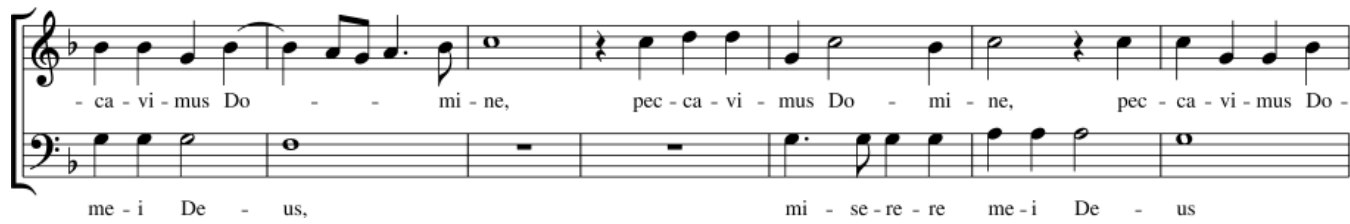

Ex. 3. Paulus Bucenus, Peccavimus Domine a 5: D, B.

In the context of the reciting tone, one cannot ignore Bucenus's Latin Passion, belonging to the genre of summa passionis. Working as a cantor in Torun, the composer wrote a letter to the City Council there, on 22 December 1571, in which he complained that he was obliged to sing with his pupils, on every Friday, the Passion at the church of St John the Baptist and St John the Evangelist; this was a wasted effort, since nobody, or almost nobody, listened to these performances ${ }^{19}$. The composer's complaint is significant for two reasons: firstly, it reveals the existence in Torun of a practice, not known from elsewhere, of singing the Passion outside the period of Easter Week. Secondly, it might suggest that this obligation, onerous for the composer, inspired him in some way to write his Passio Domini Nostri Jesu Christi, which was published in Szczecin seven years later. This composition comprises three parts and has a relatively simple homorhythmic texture. Among the six voices only the bass and the sexta vox require male singers, the others may be sung by boys' voices. These features may indicate that the composition was intended for performance by a school choir of beginners in the musical art. In the

19 Archiwum Państwowe w Toruniu [State Archive in Toruń], Kat II, X/2, pp. 168-169. 
tenor the composer uses a quasi-reciting tone: the dominant note here is $\mathrm{c}^{1}$ repeated many times over long segments. However, in the same voice we find fragments in which the melody is shaped quite freely, and thus it is difficult to see the presence of chant cantus firmus. Melodic features of the reciting kind also appear in the other voices, particularly the highest one, which means that references to chant Passion in this composition are quite clear.

Some of Bucenus's experiments with chant cantus firmus lead, probably intentionally, to effects which are not exactly desirable in liturgy. In the motet Vita in ligno moritur $(1 / 2 / 20)$ with a text taken from the sequence for Good Friday, the composer placed the chant melody in the tenor. He set it in long rhythmic values, and repeating the first verse even doubled their length. Thus the tenor, in which we find breves, longs and maxilongs, by its staticity provides a clear contrast to the discantus, which moves in semibreves, mimims and semiminims. Since the same text appears in both these voices, there have to be many repetitions of words and melismas in the higher voice. In the second part of this motet, in a number of places the composer introduced virtuoso passages in semiminims. It is difficult to imagine a performance of such a composition during the liturgy of Good Friday (Ex. 4).

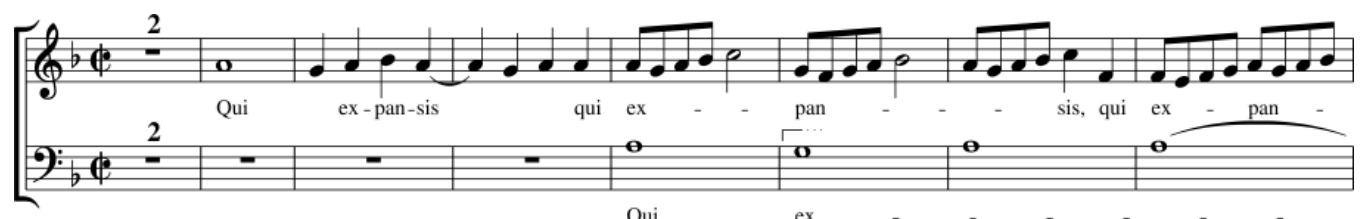

Qui

ex

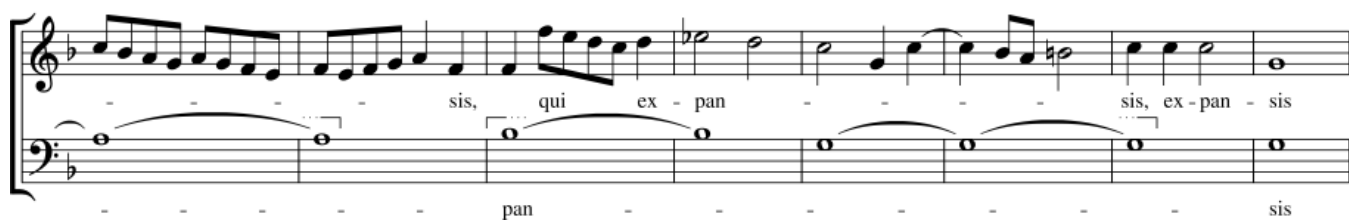

Ex. 4. Paulus Bucenus, Vita in ligno moritur: 2. pars Qui expansis in cruce a 5: D, B.

Another example of unconventional use of a chant melody is the motet Veni redemptor gentium (1/2/8). In both surviving voices there appears the melody of a Gregorian Advent hymn. In the tenor it is limited to the incipit in long but differentiated values. In the discantus it is quoted over the whole voice but undergoes transformations: all the segments of the hymn with the exception of the first one are repeated once or twice, first only to the middle of its length, and for the last time in full. The text of the given verse is repeated with the melody, either in part or in full. The hymn Veni redemptor gentium was very well known in the Lutheran community, above all in the form of the German arrangement Nun komm, der Heiden Heiland. However, in his motet Bucenus used a somewhat different version of Veni redemptor gentium from the one which served as the basis 
for the arrangement just referred to (differences appear in the melody of the second and fourth verses), and thus it is unlikely that he intended to make a direct reference to the Lutheran chant. The repetitions of melody and text, breaking off in the middle of the verse, create the impression of stammering, making the hymn less dignified and almost turning it into a travesty of itself (Ex. 5).
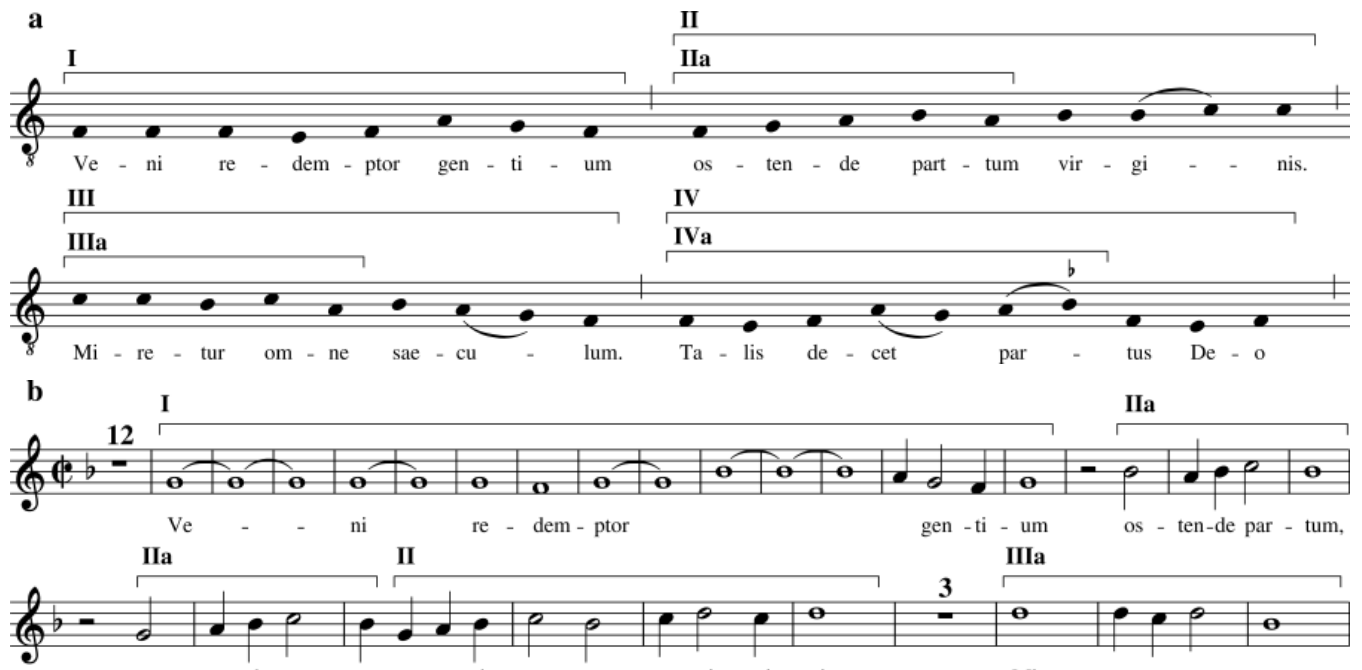

os - ten - de par - tum, os-ten-de par - tum vir - gi - nis.

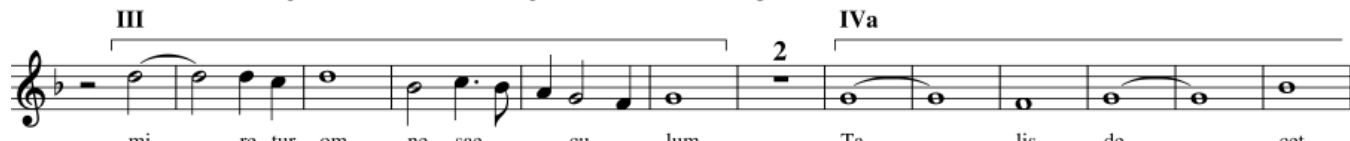

mi - re-tur om - ne sae - cu - lum.

Ta - - lis de - $\quad$ cet

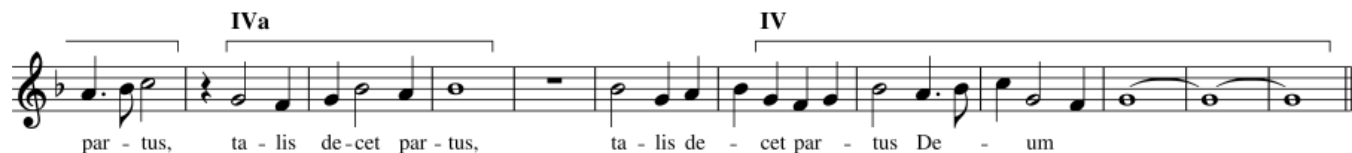

Ex. 5. a) Gregorian chant Veni redemptor gentium, b) Paulus Bucenus, Veni redemptor gentium a 5: D.

We learn from the title of the first volume of Opus musicum that the composer included in it works which might be performed by pupils; he probably had his own charges in mind. He thus combined, in some compositions, a didactic aim with a playful game which might help to initiate the youngsters into the mysteries of musical art.

Translated by Zofia Weaver 


\section{Bibliography}

\section{Sources}

\section{Manuscripts}

Berlin, Staatsbibliothek zu Berlin - Preußischer Kulturbesitz, Ms Mus. 40074 [D-B 40074].

Toruń, Archiwum Państwowe w Toruniu [State Archive in Toruń], Kat II, X/2 , pp. 168-169.

\section{Prints}

BUCENUS, Paulus. Passio Domini nostri Jesu Christi, Musicis numeris exornata, in usum Ecclesiae Rigensis. Stettin: Andreas Keller, 1578 [B 4860].

Gratulationes in honorem... Eliae Andreae Saxohalensis, cum illi Magisterii Philosophici gradus in Academia Francofordiana... ab amici scripti. Frankfurt/Oder: Andreas Eichorn, 1588.

\section{Literature, music editions}

BLANkenburG, Walter. Bucenus, Paulus. In The New Grove Dictionary of Music and Musicians. Stanley Sadie - John Tyrrell (eds.), 2nd Edition, vol. 4, London: Macmillan Publishers Ltd, 2001, pp. 531-532.

BOHN, Emil. Die Musikalischen Handschriften des XVI und XVII Jahrhunderts in der Stadtbibliothek zu Breslau. Breslau, 1890.

HAHN Gerhard - HENKYS, Jürgen (eds.). Liederkunde zum Evangelischen Gesangbuch. Heft 6/7, Göttingen: Vandenhoeck \& Ruprecht, 2003.

HEMMING, Sture. Cantor Paulus Bucenus and his Opus Musicum Ecclesiae Rigensis. Journal of Baltic Studies. 1977, vol. 8, pp. 232-237.

KEUSSLER, Gerhard von. Paulus Bucaenus, Riga: G. Löffler, 1931.

KRÜGER, Karl. Mitteilungen aus der Geschichte der Stadt Lieberose und der Gegend zunächst bis 1700. Frankfurt/Oder: Selbstverlag des Verfassers, 1891.

LESZCZYŃSKA, Agnieszka. Confessionalism in the Music of Paul Bucenus. In Musica Antiqua Europeae Orientalis, Acta Musicologica, vol. XIV. Irena Poniatowska (ed.), Bydgoszcz: Filharmonia Pomorska im. I. Paderewskiego, 2008, pp. 81-87.

MADGWICK, Paul. Music in Riga towards the end of the 16th century and Paulus Bucenus Philorhodus. In Music History Writing and National Culture: Proceedings of a Seminar. Urve Lippus (ed.). Tallinn: Eeste keele instituut, 1995, pp. 44-53 [= online, cit. 2015-11-28]. URL: https:// www.jiscmail.ac.uk/cgi-bin/filearea.cgi?LMGT1=MED-AND-REN-MUSIC\&a=get\&f=/riga.txt.

MADGWICK, Paul (ed.). Passio Domini nostri Jesu Christi, Musicis numeris exornata, in usum Ecclesiae Rigensis à Paulo Buceno Philorodo, Scholae Rigensis Cantore. 1578. Riga: Musica Baltica Ltd, 1995.

ZAGER, Daniel. The Cantica sacra (Hamburg, 1588) of Franz Eler: Latin Chant and German Chorales for the Lutheran Liturgy. In Thine the Amen: Essays on Lutheran Church Music in Honor of Carl Schalk. Carlos R. Messerli (ed.), Minneapolis: Lutheran University, 2005, pp. 43-63. 